\title{
Thrombosis - besieged but poorly understood
}

\author{
Irene M. Lang* \\ Division of Cardiology, Department of Internal Medicine II, Vienna General Hospital, Medical University of Vienna, Vienna, Austria \\ ${ }^{*}$ Correspondence: irene.lang@meduniwien.ac.at \\ Edited by: \\ Matthias Barton, University of Zurich, Switzerland \\ Reviewed by: \\ Burak Pamukcu, Erdem Hospital, Turkey \\ Ingo Ahrens, Universitäts-Herzzentrum Freiburg Bad Krozingen, Germany
}

Keywords: thrombosis, vascular biology, myocardial infarction, stroke, venous thromboembolism

In biology, thrombosis is a mechanism of maintaining the integrity of biological surfaces in higher mammals, limiting fluid loss, and facilitating the recognition, containment, and destruction of pathogens and foreign materials by a scaffold of fibrin and DNA strands. However, thrombosis may also lead to vascular occlusion and subsequent tissue damage.

In medicine, thrombosis is a hallmark of life-threatening cardiovascular diseases, such as myocardial infarction, stroke, or venous thromboembolism representing major causes of death in the Western civilization. Every year 17 million individuals die from cardiovascular disease (1, 2 ), comprising almost half of the global death toll in Europe. For example, in Austria, 34,000 patients suffered a cardiovascular death in 2012, accounting for $42.7 \%$ of all deaths, which is 1.7 -fold the death toll of malignant diseases (3).

Cardiovascular science beyond clinical observation and anatomical dissection emerged in the late 19th and early 20th centuries. A key observation was the epidemiological connection of hypertension and elevated plasma lipids with atherosclerotic vascular disease (4). Based on a more profound understanding of these risk factors, including exercise, body weight, and glucose metabolism, preventive measures were tested, leading to both primary and secondary preventions that have become powerful modulators of disease decreasing events by almost half. Since then, the establishment of coronary care units, cardiac catheterization, angioplasty, and surgery and the advent of modern medications many of which interfere with thrombosis and platelet aggregation, have contributed to fundamental improvements in cardiovascular care. However, much of the advances in cardiovascular science have been in the thrombosis field, stimulated by the discovery that myocardial infarction was due to thrombi in the coronary arteries (5). Traditionally, thrombosis has been viewed as the biochemical result of regulated cascades of protein interactions characterized by the activation of factor $\mathrm{X}$ and the activation of thrombin, resulting in the formation of fibrin. Accordingly, treatments for myocardial infarction, stroke, and venous thromboembolism have targeted pathways or more recently, individual protein moieties (Figure 1). Table 1 summarizes landmark trials leading to the approval of individual compounds. Over 50 years, a plethora of treatments has been brought to market (Table 1), with high efficacy and safety profiles that have contributed to the observation that death rates per 100,000 population were decreased from 450 in the 1950s to 150 around 2010 (6). For example, while $20-30 \%$ of hospitalized patients with myocardial infarction died within 30 days due to their underlying disease, this number has been substantially decreased to $<5 \%$ most recently ( 7 ).

The public domain is thrilled with advances of cardiovascular medicine, and needs for deeper insights are hardly convincing in an environment of harmonized health care providing infarction networks, stent-for-life programs, and generally high standard guidelines in cardiovascular care.

However, do we understand thrombosis, do we understand recurrence, or do we prefer, for example, to mandate life-long factor X inhibition (38, 46-48) and statins (49) in patients at risk, without further investigation of underlying mechanisms?
More recently, a new view of thrombosis has emerged accounting for thrombosis as a vascular disease involving the dynamic interaction between platelets, circulating inflammatory cells, nucleic acids and proteins, and resident cells of the vascular wall. Milestones along the way of integrating the vessel wall in the thrombotic process were the discovery and action of nitric oxide (50, 51), the delineation of the LDL-cholesterol pathway $(52,53)$, the role of soluble and membrane bound tissue factor in atherosclerosis (54), and most recently the concept of "immunothrombosis" (55), linking inflammation and thrombosis as regulators of vascular integrity. Consequently, it was understood that the hemostatic system is a modulator of atherosclerosis (56). Thrombosis comprises both acute clotting and the more time-consuming process of thrombus resolution, which represents a vascular remodeling process that is driven by inflammation, angiogenesis, and cells of the innate immune system. A stimulus leading to thrombus formation induces an innate immune response that is supported by neutrophils, lymphocytes, macrophages, by specific thrombosis-related molecules, and neutrophil extracellular traps (NETS), underpinning the importance of the following questions:

Is thrombosis the underlying process behind both arterial and venous disease that oftentimes combines in individual patients? (57) Do we understand endothelial dysfunction, and is it the nidus for thrombosis, and eventually vascular occlusion? And why do acute pulmonary emboli transform into chronic vascular obstructions in chronic thromboembolic pulmonary hypertension? Do 


\section{Antithrombotic und Antiplatelet Tx}

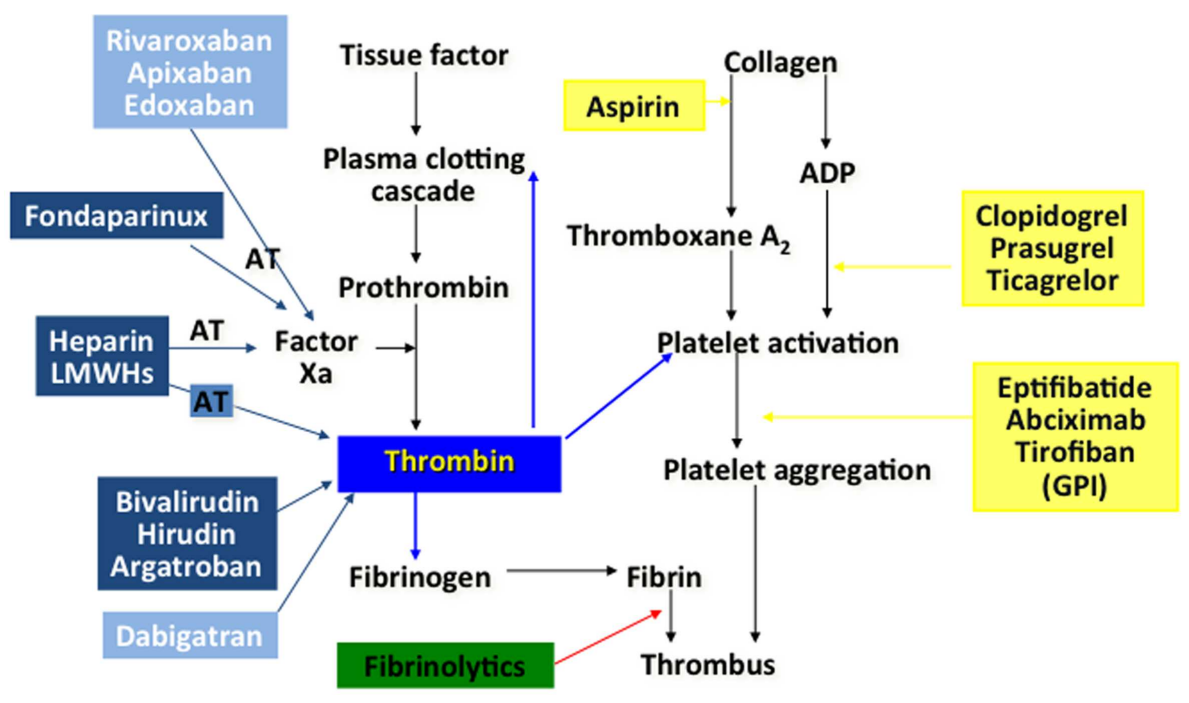

FIGURE 1 | Process of coagulation and the primary sites of action of current pharmacologic agents

Table 1 | Overview of treatments approved for vascular thrombosis (antithrombotics, comprising thrombolytics, anticoagulants, and antiplatelet drugs).

\begin{tabular}{|c|c|c|c|c|}
\hline Concept & $\begin{array}{l}\text { Mechanism of } \\
\text { action }\end{array}$ & $\begin{array}{l}\text { Compound } \\
\text { (key reference) }\end{array}$ & Indication & Benefits/Harms \\
\hline \multirow[t]{7}{*}{$\begin{array}{l}\text { Antiplatelet } \\
\text { drugs }\end{array}$} & COX inhibition & $\begin{array}{l}\text { Acetylsalicylic } \\
\text { acid/Aspirin (8) }\end{array}$ & Prevention of cardiovascular events & $\begin{array}{l}\text { Increased risk of bleeding when } \\
\text { combined with NSAIDs }\end{array}$ \\
\hline & $\begin{array}{l}\text { ADP receptor/ } \\
\mathrm{P}_{2} \mathrm{Y}_{12} \text { inhibition }\end{array}$ & Clopidogrel (9) & Prevention of thrombotic events & $\begin{array}{l}\text { Pro-drug limited by metabolization, } \\
\text { irreversible }\end{array}$ \\
\hline & & Clopidogrel (10) & ACS & $\begin{array}{l}\text { Pro-drug limited by metabolization, } \\
\text { irreversible }\end{array}$ \\
\hline & & Prasugrel $(11,12)$ & Prevention of thrombotic events & $\begin{array}{l}\text { Rapid onset of action, high efficacy, } \\
\text { particularly in diabetic subjects, } \\
\text { increased bleeding rates in those aged } \\
>75 \text { years, and in those with previous } \\
\text { stroke and a weight less than } 60 \mathrm{~kg} \text {, } \\
\text { irreversible }\end{array}$ \\
\hline & & Ticagrelor (13) & $\begin{array}{l}\text { Prevention of thrombotic events } \\
\text { particularly in STE-ACS }\end{array}$ & $\begin{array}{l}\text { Rapid onset of action, reversible, high } \\
\text { efficacy, low bleeding rates, provides a } \\
\text { survival benefit in ACS }\end{array}$ \\
\hline & $\begin{array}{l}\text { Phosphodiesterase } \\
\text { inhibition }\end{array}$ & Cilostazol (14) & $\begin{array}{l}\text { Reduction of symptoms of intermittent } \\
\text { claudication }\end{array}$ & $\begin{array}{l}\text { Phosphodiesterase } 3 \text { inhibitor, } \\
\text { potentially dangerous in severe heart } \\
\text { failure }\end{array}$ \\
\hline & $\begin{array}{l}\text { Glycoprotein } \\
\text { Ilb/IIla inhibition }\end{array}$ & Abciximab $(15,16)$ & $\begin{array}{l}\text { For use in individuals undergoing } \mathrm{PCl} \text { with } \\
\text { or without stent placement to decrease } \\
\text { the incidence of ischemic complications } \\
\text { due to the procedure }\end{array}$ & $\begin{array}{l}\text { Effective prevention of ischemic } \\
\text { events, particularly in diabetic subjects, } \\
\text { and subjects with chronic kidney } \\
\text { disease, increased bleeding rates only } \\
\text { in high-risk patients }\end{array}$ \\
\hline
\end{tabular}




\section{Table 1 | Continued}

\begin{tabular}{lll}
\hline Concept & $\begin{array}{l}\text { Mechanism of } \\
\text { action }\end{array}$ & $\begin{array}{l}\text { Compound } \\
\text { (key reference) }\end{array}$ \\
\hline Tirofiban (17) & $\begin{array}{l}\text { Reduction of the rate of thrombotic } \\
\text { cardiovascular events (combined endpoint } \\
\text { of death, myocardial infarction, or } \\
\text { refractory ischemia/repeat cardiac }\end{array}$ \\
& procedure) in patients with NSTE-ACS \\
& Reduction of the risk of acute cardiac \\
& ischemic events (death and/or myocardial \\
& infarction) in patients with UA or \\
& NSTE-ACS both in patients who are to \\
& receive medical treatment and those \\
& undergoing PCl
\end{tabular}

\section{Anticoagulants Vitamin K Vitamin K antagonists antagonism \\ (19)}

Factor Xa inhibition

\author{
Unfractionated heparin \\ (20-23) new ESC \\ Guidelines pending \\ 2014 \\ Low-molecular weight \\ heparins, e.g., \\ enoxaparin $(23,24)$ \\ Low-molecular weight \\ heparins, e.g., \\ enoxaparin $(25,26)$ \\ Low-molecular weight \\ heparins, e.g., \\ enoxaparin (27) \\ Fondaparinux (28)
}

Fondaparinux (29)

Rivaroxaban (30)

Rivaroxaban (31)
Prevention and treatment of venous thromboembolism, atrial fibrillation, mechanical and bioprosthetic heart valves, post-myocardial infarction, recurrent systemic embolism and other indications

Deep vein thrombosis (DVT) in patients with renal failure

Prevention of DVT in hip or knee replacement surgery, or in abdominal surgery or acutely ill patients with severely restricted mobility at risk for thromboembolism Prevention of ischemic complications of UA and NSTE-ACS. STE-ACS managed medically or with subsequent $\mathrm{PCl}$ Acute pulmonary embolism

ACS

Prophylaxis of DVT in patients undergoing hip facture surgery, hip replacement surgery and knee replacement surgery.

VTE prophylaxis

Non-valvular atrial fibrillation

\section{Benefits/Harms}

Rapid onset and short duration of action (4-8h)

Short half-life

Accepted standard, reproducible results, high exposure rates, cheap, no contraindication in patients with GFR $<30 \mathrm{~mL} / \mathrm{min}$

HIT possible

Accumulates in chronic renal failure

Accumulates in chronic renal failure

Accumulates in chronic renal failure

Positive effect on survival, thrombus formation on wires/balloons during (primary) $\mathrm{PCl}$ if no additional heparin is used, contraindicated in severe renal failure with a GFR $<20 \mathrm{~mL} / \mathrm{min}$ $50 \%$ VTE risk reduction compared with enoxaparin, no increase in clinically relevant bleeding Contraindicated in severe renal failure with a GFR $<20 \mathrm{~mL} / \mathrm{min}$

Easy administration, once daily, more effective compared with enoxaparin, same safety profile

Non-inferior to warfarin for the prevention of stroke or systemic embolism, same risk of major bleeding, however, less intracranial and fatal 


\section{Table 1 | Continued}

\begin{tabular}{|c|c|c|c|c|}
\hline Concept & $\begin{array}{l}\text { Mechanism of } \\
\text { action }\end{array}$ & $\begin{array}{l}\text { Compound } \\
\text { (key reference) }\end{array}$ & Indication & Benefits/Harms \\
\hline & \multirow{8}{*}{$\begin{array}{l}\text { Direct thrombin } \\
\text { (II) inhibition }\end{array}$} & Rivaroxaban (32) & $\begin{array}{l}\text { Reduction of the risk of recurrent } \\
\text { atherothrombotic events in patients with } \\
\text { acute coronary syndromes }\end{array}$ & $\begin{array}{l}\text { Less cardiovascular death, myocardial } \\
\text { infarction and stroke, but increased risk } \\
\text { of major bleeding and intracranial } \\
\text { hemorrhage, but not fatal bleeding }\end{array}$ \\
\hline & & Apixaban (33) & Non-valvular atrial fibrillation & $\begin{array}{l}\text { Compared with warfarin less ischemic } \\
\text { strokes }\end{array}$ \\
\hline & & Apixaban (34) & VTE prophylaxis & $\begin{array}{l}\text { Superior to enoxaparin in preventing } \\
\text { thrombosis }\end{array}$ \\
\hline & & Lepirudin (35) & ACS & Low exposure rates, little information \\
\hline & & Bivalirudin (36) & ACS & $\begin{array}{l}\text { Survival benefit, however, signal of } \\
\text { increased early stent thrombosis }\end{array}$ \\
\hline & & Dabigatran (38) & $\begin{array}{l}\text { Reduction of the risk of recurrence of DVT } \\
\text { and pulmonary embolism }\end{array}$ & $\begin{array}{l}\text { Compared with warfarin less } \\
\text { hemorrhagic strokes, mild increase of } \\
\text { GI bleeds, antibody-based antidote in } \\
\text { development }\end{array}$ \\
\hline & & Dabigatran (39) & $\begin{array}{l}\text { Treatment of DVT and pulmonary } \\
\text { embolism }\end{array}$ & $\begin{array}{l}\text { Compared with warfarin less } \\
\text { hemorrhagic strokes, mild increase of } \\
\text { GI bleeds, antibody-based antidote in } \\
\text { development }\end{array}$ \\
\hline & & Argatroban (40) & $\begin{array}{l}\text { Prophylaxis or treatment of thrombosis in } \\
\text { patients with heparin-induced } \\
\text { thrombocytopenia; including patients } \\
\text { undergoing PCl }\end{array}$ & Low exposure rates, low case numbers \\
\hline & & Alteplase (43) & Acute ischemic stroke & $\begin{array}{l}\text { Recombinant tissue-type plasminogen } \\
\text { activator with improved fibrin binding }\end{array}$ \\
\hline & & Reteplase (44) & Acute coronary syndrome & $\begin{array}{l}\text { longer half-life, better penetration into } \\
\text { thrombus }\end{array}$ \\
\hline & & Tenecteplase (45) & $\begin{array}{l}\text { Reduction of mortality associated with } \\
\text { acute myocardial infarction }\end{array}$ & $\begin{array}{l}\text { higher fibrin specificity and greater } \\
\text { resistance to inactivation by its } \\
\text { endogenous inhibitor (PAI-1) compared } \\
\text { to native t-PA }\end{array}$ \\
\hline
\end{tabular}

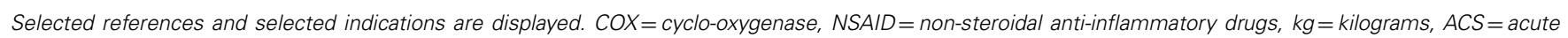

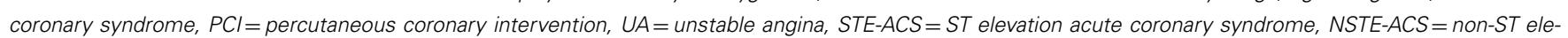

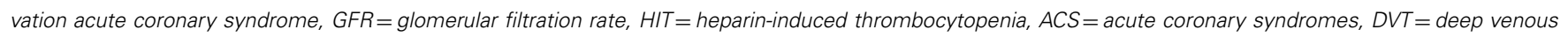
thrombosis, VTE = venous thromboembolism, Gl=gastro-intestinal, PAl-1=plasminogen activator inhibitor type 1, t-PA = tissue-type plasminogen activator.

we understand acute vascular syndromes simply by plaque rupture that is driven by macrophages that are loaded with lipids, and proteolytically cleave a thincap fibroatheroma thus triggering platelet activation? Does that concept explain acute coronary syndromes in young subjects without significant vascular stenoses? Is thrombosis per se the trigger for all vascular occlusion, be it chronic or acute?
Is vascular occlusion the sequlae of deficient efferocytosis, and are those mechanisms driven by a deficiency of natural antibodies? What are the recognition sites for natural antibodies in the circulation? 
Which cells or cell fragments in the circulation are carrying oxidation specific epitopes, e.g., oxidized low-density lipoprotein (OxLDL) or malon-dialdehyde, and how do they function as danger associated molecular patterns? What is the role of nucleic acids, RNAse, and DNAse in thrombosis? Is NETting a preventable amplifier of acute thrombosis and the adverse vascular remodeling following thrombosis?

Are there potential therapeutic targets, upstream of mechanisms of thrombosis that might be applied without any potential bleeding risk? And might addressing those new targets prevent recurrence? Will we be able to identify a cellular program to minimize the potential of thrombosis and vascular occlusion? Will we be restoring normal $\mathrm{Ca}^{2+}$ cycling and reduce reperfusion injury? Will we be utilizing therapeutic antagomirs to control cellular responses to vascular injury? Will we be engineering vessels and vascular compartments of organ systems?

While bench-top research will address these questions, clinical research will complement advances both in drug-based trials and in interventional approaches. Since the PEITHO trial, the term of acute pulmonary revascularization has been coined in analogy to coronary revascularization, leading the way to interventional treatments (58) as adjunct or stand-alone treatments for the pulmonary circulation. Similar developments have recently been initiated in chronic pulmonary vascular disease and will change treatment paradigms (59-62).

Taken together, thrombosis is an important mediator of vascular disease, but cannot be seen in isolation. Data suggest that it most often occurs as the consequence of a loss of vascular barrier function, for example, in the context of inflammation and rarely as a primary event. To comprehend mechanisms of vascular barrier function is another challenge of thrombosis research of the future. To understand thrombosis, we need to look beyond thrombosis.

\section{REFERENCES}

1. Murray CJ, Lopez AD. Measuring the global burden of disease. N Engl J Med (2013) 369:448-57. doi:10.1056/NEJMra1201534

2. Laslett LJ, Alagona P Jr., Clark BA III, Drozda JP Jr., Saldivar F, Wilson SR, et al. The worldwide environment of cardiovascular disease: prevalence, diagnosis, therapy, and policy issues: a report from the American College of Cardiology. J Am Coll Cardiol (2012) 60:S1-49. doi:10.1016/j.jacc.2012. 11.002

3. Schneider B. Statistik Austria 2012. Österreichische Ärztezeitung (2013):doi:10.3109/02699052.2014. 904522

4. Kannel WB, Dawber TR, Kagan A, Revotskie N, Stokes J III. Factors of risk in the development of coronary heart disease - six year follow-up experience. The Framingham Study. Ann Intern Med (1961) 55:33-50. doi:10.7326/0003-4819-551-33

5. Hektoen L. Embolism of the left coronary artery; sudden death. Med Newsl (London) (1892) 61:210.

6. Nabel EG, Braunwald E. A tale of coronary artery disease and myocardial infarction. $N$ Engl J Med (2012) 366:54-63. doi:10.1056/NEJMral112570

7. Kalla K, Christ G, Karnik R, Malzer R, Norman $\mathrm{G}$, Prachar $\mathrm{H}$, et al. Implementation of guidelines improves the standard of care: the Viennese registry on reperfusion strategies in STelevation myocardial infarction (Vienna STEMI registry). Circulation (2006) 113:2398-405. doi:10. 1161/CIRCULATIONAHA.105.586198

8. Lewis HD Jr., Davis JW, Archibald DG, Steinke WE, Smitherman TC, Doherty JE III, et al. Protective effects of aspirin against acute myocardial infarction and death in men with unstable angina. Results of a Veterans Administration Cooperative Study. N Engl J Med (1983) 309:396-403. doi:10.1056/NEJM198308183090703

9. Committee CS. A randomised, blinded, trial of clopidogrel versus aspirin in patients at risk of ischaemic events (CAPRIE). CAPRIE Steering Committee. Lancet (1996) 348:1329-39. doi:10. 1016/S0140-6736(96)09457-3

10. Yusuf S, Zhao F, Mehta SR, Chrolavicius S, Tognoni G, Fox KK, et al. Effects of clopidogrel in addition to aspirin in patients with acute coronary syndromes without ST-segment elevation. N Engl J Med (2001) 345:494-502. doi:10.1056/ NEJMoa010746

11. Montalescot G, Wiviott SD, Braunwald E, Murphy SA, Gibson CM, Mccabe $\mathrm{CH}$, et al. Prasugrel compared with clopidogrel in patients undergoing percutaneous coronary intervention for STelevation myocardial infarction (TRITON-TIMI 38): double-blind, randomised controlled trial. Lancet (2009) 373:723-31. doi:10.1016/S01406736(09)60441-4

12. Wiviott SD, Braunwald E, Angiolillo DJ, Meisel S, Dalby AJ, Verheugt FW, et al. Greater clinical benefit of more intensive oral antiplatelet therapy with prasugrel in patients with diabetes mellitus in the trial to assess improvement in therapeutic outcomes by optimizing platelet inhibition with prasugrel-Thrombolysis in Myocardial Infarction 38. Circulation (2008) 118:1626-36. doi:10.1161/ CIRCULATIONAHA.108.791061

13. Wallentin L, Becker RC, Budaj A, Cannon CP, Emanuelsson H, Held C, et al. Ticagrelor versus clopidogrel in patients with acute coronary syndromes. N Engl J Med (2009) 361:1045-57. doi:10.1056/NEJMoa0904327

14. Stevens JW, Simpson E, Harnan S, Squires H, Meng Y, Thomas S, et al. Systematic review of the efficacy of cilostazol, naftidrofuryl oxalate and pentoxifylline for the treatment of intermittent claudication. Br J Surg (2012) 99:1630-8. doi:10. 1002/bjs.8895

15. Lefkovits J, Ivanhoe RJ, Califf RM, Bergelson BA, Anderson KM, Stoner GL, et al. Effects of platelet glycoprotein IIb/IIIa receptor blockade by a chimeric monoclonal antibody (abciximab) on acute and six-month outcomes after percutaneous transluminal coronary angioplasty for acute myocardial infarction. EPIC investigators. Am J Cardiol (1996) 77:1045-51. doi:10.1016/S00029149(96)00128-2

16. Stone GW, Maehara A, Witzenbichler B, Godlewski $\mathrm{J}$, Parise $\mathrm{H}$, Dambrink $\mathrm{JH}$, et al. Intracoronary abciximab and aspiration thrombectomy in patients with large anterior myocardial infarction: the INFUSE-AMI randomized trial. JAMA (2012) 307:1817-26. doi:10.1001/jama.2012.421

17. Van't Hof AW, Ten Berg J, Heestermans T, Dill T, Funck RC, Van Werkum W, et al. Prehospital initiation of tirofiban in patients with STelevation myocardial infarction undergoing primary angioplasty (On-TIME 2): a multicentre, double-blind, randomised controlled trial. Lancet (2008) 372:537-46. doi:10.1016/S0140-6736(08) 61235-0

18. O'shea JC, Hafley GE, Greenberg S, Hasselblad V, Lorenz TJ, Kitt MM, et al. Platelet glycoprotein IIb/IIIa integrin blockade with eptifibatide in coronary stent intervention: the ESPRIT trial: a randomized controlled trial. JAMA (2001) 285:2468-73. doi:10.1001/jama.285.19.2468

19. Ansell J, Hirsh J, Poller L, Bussey H, Jacobson A, Hylek E. The pharmacology and management of the vitamin K antagonists: the Seventh ACCP Conference on Antithrombotic and Thrombolytic Therapy. Chest (2004) 126:204S-33S. doi:10.1378/ chest.126.3_suppl.204S

20. Best CH, Bauer G. Heparin and thrombosis: Harvey lecture, November 28, 1940. Bull N Y Acad Med (1941) 17:796-817.

21. Bauer G. Thrombosis; early diagnosis and abortive treatment with heparin. Lancet (1946) 247:447-54. doi:10.1016/S0140-6736(46) 91429-8

22. Torbicki A, Perrier A, Konstantinides S, Agnelli G, Galie N, Pruszczyk P, et al. Guidelines on the diagnosis and management of acute pulmonary embolism: the Task Force for the Diagnosis and Management of Acute Pulmonary Embolism of the European Society of Cardiology (ESC). Eur Heart J (2008) 29:2276-315. doi:10.1093/ eurheartj/ehn310

23. Holbrook A, Schulman S, Witt DM, Vandvik PO, Fish J, Kovacs MJ, et al. Evidence-based management of anticoagulant therapy: Antithrombotic Therapy and Prevention of Thrombosis, 9th ed: American College of Chest Physicians EvidenceBased Clinical Practice Guidelines. Chest (2012) 141:152S-84S. doi:10.1378/chest.11-2295

24. ENOXACAN Study Group. Efficacy and safety of enoxaparin versus unfractionated heparin for prevention of deep vein thrombosis in elective cancer surgery: a double-blind randomized multicentre trial with venographic assessment. Br J Surg (1997) 84:1099-103. doi:10.1046/j.1365-2168.1997.d013882.x 
25. Hamm CW, Bassand JP, Agewall S, Bax J, Boersma E, Bueno $\mathrm{H}$, et al. ESC Guidelines for the management of acute coronary syndromes in patients presenting without persistent ST-segment elevation: The Task Force for the management of acute coronary syndromes (ACS) in patients presenting without persistent ST-segment elevation of the European Society of Cardiology (ESC). Eur Heart J (2011) 32:2999-3054. doi:10.1093/ eurheartj/ehr236

26. Task Force M, Montalescot G, Sechtem U, Achenbach S, Andreotti F, Arden C, et al. 2013 ESC guidelines on the management of stable coronary artery disease: the Task Force on the management of stable coronary artery disease of the European Society of Cardiology. Eur Heart J (2013) 34:2949-3003. doi:10.1093/eurheartj/eht296

27. Simonneau G, Sors H, Charbonnier B, Page Y, Laaban JP, Azarian R, et al. A comparison of low-molecular-weight heparin with unfractionated heparin for acute pulmonary embolism. The THESEE Study Group. Tinzaparine ou Heparine Standard: Evaluations dans l'Embolie Pulmonaire. $N$ Engl J Med (1997) 337:663-9. doi:10.1056/ NEJM199709043371002

28. Fifth Organization to Assess Strategies in Acute Ischemic Syndromes, Yusuf S, Mehta SR, Chrolavicius S, Afzal R, Pogue J, et al. Comparison of fondaparinux and enoxaparin in acute coronary syndromes. N Engl J Med (2006) 354:1464-76. doi:10.1056/NEJMoa055443

29. Turpie A, Bauer K, Eriksson B, Lassen M, Steering Committees of the Pentasaccharide Orthopedic Prophylaxis. Efficacy and safety of fondaparinux in major orthopedic surgery according to the timing of its first administration. Thromb Haemost (2003) 90:364-6. doi:10.1267/THRO03020364

30. Lassen MR, Ageno W, Borris LC, Lieberman JR, Rosencher N, Bandel TJ, et al. Rivaroxaban versus enoxaparin for thromboprophylaxis after total knee arthroplasty. N Engl J Med (2008) 358:2776-86. doi:10.1056/NEJMoa076016

31. Patel MR, Mahaffey KW, Garg J, Pan G, Singer DE, Hacke W, et al. Rivaroxaban versus warfarin in nonvalvular atrial fibrillation. N Engl J Med (2011) 365:883-91. doi:10.1056/NEJMoa1009638

32. Mega JL, Braunwald E, Wiviott SD, Bassand J-P, Bhatt DL, Bode C, et al. Rivaroxaban in patients with a recent acute coronary syndrome. $N$ Engl J Med (2012) 366:9-19. doi:10.1056/ NEJMoa 1112277

33. Granger CB, Alexander JH, Mcmurray JJ, Lopes RD, Hylek EM, Hanna M, et al. Apixaban versus warfarin in patients with atrial fibrillation. $N$ Engl J Med (2011) 365:981-92. doi:10.1056/ NEJMoa1107039

34. Lassen MR, Raskob GE, Gallus A, Pineo G, Chen D, Hornick P, et al. Apixaban versus enoxaparin for thromboprophylaxis after knee replacement (ADVANCE-2): a randomised double-blind trial. Lancet (2010) 375:807-15. doi:10.1016/S01406736(09)62125-5

35. Organisation to Assess Strategies for Ischemic Syndromes (OASIS-2) Investigators. Effects of recombinant hirudin (lepirudin) compared with heparin on death, myocardial infarction, refractory angina, and revascularisation procedures in patients with acute myocardial ischaemia without
ST elevation: a randomised trial. Lancet (1999) 353:429-38.

36. Stone GW, White HD, Ohman EM, Bertrand ME, Lincoff AM, Mclaurin BT, et al. Bivalirudin in patients with acute coronary syndromes undergoing percutaneous coronary intervention: a subgroup analysis from the Acute Catheterization and Urgent Intervention Triage strategy (ACUITY) trial. Lancet (2007) 369:907-19. doi:10.1016/ S0140-6736(07)60450-4

37. Wallentin L, Yusuf S, Ezekowitz MD, Alings M, Flather M, Franzosi MG, et al. Efficacy and safety of dabigatran compared with warfarin at different levels of international normalised ratio control for stroke prevention in atrial fibrillation: an analysis of the RE-LY trial. Lancet (2010) 376:975-83. doi:10.1016/S0140-6736(10)61194-4

38. Schulman S, Kearon C, Kakkar AK, Schellong S, Eriksson H, Baanstra D, et al. Extended use of dabigatran, warfarin, or placebo in venous thromboembolism. N Engl J Med (2013) 368:709-18. doi:10.1056/NEJMoa1113697

39. Schulman S, Kakkar AK, Goldhaber SZ, Schellong S, Eriksson H, Mismetti P, et al. Treatment of acute venous thromboembolism with dabigatran or warfarin and pooled analysis. Circulation (2014) 129:764-72. doi:10.1161/ CIRCULATIONAHA.113.004450

40. Dasararaju R, Singh N, Mehta A. Heparin induced thrombocytopenia: review. Expert Rev Hematol (2013) 6:419-28. doi:10.1586/17474086.2013. 814446

41. Ly B, Arnesen H, Eie H, Hol R. A controlled clinical trial of streptokinase and heparin in the treatment of major pulmonary embolism. Acta Med Scand (1978) 203:465-70. doi:10.1111/j.0954-6820.1978. tb14909.x

42. Gruppo Italiano per lo Studio della Streptochinasi nell'Infarto Miocardico (GISSI). Effectiveness of intravenous thrombolytic treatment in acute myocardial infarction. Lancet (1986) 1:397-402.

43. The National Institute of Neurological Disorders and Stroke rt-PA Stroke Study Group. Tissue plasminogen activator for acute ischemic stroke. N Engl J Med (1995) 333:1581-7. doi:10.1056/ NEJM199512143332401

44. Weaver WD. Results of the RAPID 1 and RAPID 2 thrombolytic trials in acute myocardial infarction. Eur Heart J (1996) 17(Suppl E):14-20. doi: 10.1093/eurheartj/17.suppl_E.14

45. Van De Werf F, Adgey J, Ardissino D, Armstrong PW, Aylward P, Barbash G, et al. Singlebolus tenecteplase compared with front-loaded alteplase in acute myocardial infarction: the ASSENT-2 double-blind randomised trial. Lancet (1999) 354:716-22. doi:10.1016/S0140-6736(99) 07403-6

46. Ridker PM, Goldhaber SZ, Danielson E, Rosenberg Y, Eby CS, Deitcher SR, et al. Long-term, lowintensity warfarin therapy for the prevention of recurrent venous thromboembolism. $N$ Engl J Med (2003) 348:1425-34. doi:10.1056/NEJMoa035029

47. Romualdi E, Donadini MP, Ageno W. Oral rivaroxaban after symptomatic venous thromboembolism: the continued treatment study (EINSTEIN-extension study). Expert Rev Cardiovasc Ther (2011) 9:841-4. doi:10.1586/erc. 11.62
48. Agnelli G, Buller HR, Cohen A, Curto M, Gallus AS, Johnson M, et al. Apixaban for extended treatment of venous thromboembolism. N Engl J Med (2013) 368:699-708. doi:10.1056/NEJMoa1207541

49. Ridker PM, Danielson E, Fonseca FA, Genest J, Gotto AM Jr., Kastelein JJ, et al. Rosuvastatin to prevent vascular events in men and women with elevated C-reactive protein. N Engl J Med (2008) 359:2195-207. doi:10.1056/NEJMoa0807646

50. Furchgott RF, Zawadzki JV. The obligatory role of endothelial cells in the relaxation of arterial smooth muscle by acetylcholine. Nature (1980) 288:373-6. doi:10.1038/288373a0

51. Ignarro LJ, Buga GM, Wood KS, Byrns RE, Chaudhuri G. Endothelium-derived relaxing factor produced and released from artery and vein is nitric oxide. Proc Natl Acad Sci U S A (1987) 84:9265-9. doi:10.1073/pnas.84.24.9265

52. Goldstein JL, Brown MS. The LDL receptor. Arterioscler Thromb Vasc Biol (2009) 29:431-8. doi:10. 1161/ATVBAHA.108.179564

53. Brown MS, Goldstein JL. A receptor-mediated pathway for cholesterol homeostasis. Science (1986) 232:34-47. doi:10.1126/science.3513311

54. Nemerson Y. A different view of thrombosis. Blood Coagul Fibrinolysis (2000) 11(Suppl 1):S1-2. doi: 10.1097/00001721-200004001-00001

55. Engelmann B, Massberg S. Thrombosis as an intravascular effector of innate immunity. Nat Rev Immunol (2013) 13:34-45. doi:10.1038/ nri3345

56. Borissoff JI, Spronk HM, Ten Cate H. The hemostatic system as a modulator of atherosclerosis. N Engl J Med (2011) 364:1746-60. doi:10.1056/ NEJMra1011670

57. Sorensen HT, Horvath-Puho E, Pedersen L, Baron JA, Prandoni P. Venous thromboembolism and subsequent hospitalisation due to acute arterial cardiovascular events: a 20-year cohort study. Lancet (2007) 370:1773-9. doi:10.1016/S01406736(07)61745-0

58. Kucher N, Boekstegers P, Muller OJ, Kupatt C, Beyer-Westendorf J, Heitzer T, et al. Randomized, controlled trial of ultrasoundassisted catheter-directed thrombolysis for acute intermediate-risk pulmonary embolism. Circulation (2014) 129:479-86. doi:10.1161/CIRCULATIONAHA.113.005544

59. Sugimura K, Fukumoto Y, Satoh K, Nochioka K, Miura Y, Aoki T, et al. Percutaneous transluminal pulmonary angioplasty markedly improves pulmonary hemodynamics and long-term prognosis in patients with chronic thromboembolic pulmonary hypertension. Circ J (2012) 76:485-8. doi:10.1253/circj.CJ-11-1217

60. Kataoka M, Inami T, Hayashida K, Shimura N, Ishiguro $\mathrm{H}$, Abe $\mathrm{T}$, et al. Percutaneous transluminal pulmonary angioplasty for the treatment of chronic thromboembolic pulmonary hypertension. Circ Cardiovasc Interv (2012) 5:756-62. doi:10.1161/circinterventions.112.971390

61. Fukui S, Ogo T, Morita Y, Tsuji A, Tateishi E, Ozaki K, et al. Right ventricular reverse remodelling after balloon pulmonary angioplasty. Eur Respir J (2014) 43:1394-402. doi:10.1183/ 09031936.00012914

62. Mizoguchi H, Ogawa A, Munemasa M, Mikouchi $\mathrm{H}$, Ito H, Matsubara H. Refined balloon pulmonary 
angioplasty for inoperable patients with chronic thromboembolic pulmonary hypertension. Circ Cardiovasc Interv (2012) 5:748-55. doi:10.1161/ circinterventions.112.971077

Conflict of Interest Statement: Irene M. Lang has relationships with drug companies including AOPOrphan Pharmaceuticals, Abbott, Actelion, Astra-Zeneca, Bayer-Schering, Cordis, Glaxo Smith Kline, Medtronic, Novartis, Pfizer, Servier, and United Therapeutics. In addition to being investigator in trials involving these companies, relationships include consultancy service, research grants, and membership of scientific advisory boards.

Received: 24 June 2014; accepted: 04 August 2014; published online: 18 August 2014.

Citation: Lang IM (2014) Thrombosis - besieged but poorly understood. Front. Cardiovasc. Med. 1:4. doi: $10.3389 / f c v m .2014 .00004$
This article was submitted to Thrombosis, a section of the journal Frontiers in Cardiovascular Medicine.

Copyright (c) 2014 Lang. This is an open-access article distributed under the terms of the Creative Commons Attribution License (CC BY). The use, distribution or reproduction in other forums is permitted, provided the original author(s) or licensor are credited and that the original publication in this journal is cited, in accordance with accepted academic practice. No use, distribution or reproduction is permitted which does not comply with these terms. 